\title{
MACROECONOMIC CONDITION AND BANKING INDUSTRY PERFORMANCE IN INDONESIA
}

\author{
Mahjus Ekananda'
}

\begin{abstract}
The ratio of non-performing loan (NPL) and capital adequacy ratio (CAR) is still a measure of bank soundness in various countries including Indonesia. Interdependence acros bank's condition, diversity of the size, market structure within banking industry, and macroeconomic variables, may be very complex and dynamic. This paper utilizes the advantage of PVAR model on capturing this complexity to analyze the dynamic relationship between the macroeconomic variables and the soundness of the banks. The result shows NPL of banks with small asset will increases rapidly when interest rate fluctuates. For banks with large asset, the increase in interest rates leads to larger reduction on their CAR. On the other hand, the result shows banks with smaller capital are less able to adapt quickly to an increase in NPL due to exchange rate depreciation, therefore banks with smaller capital should be cautious about the exchange rate risk.
\end{abstract}

Keywords: Credit, PVAR, Banking, Interest Rate, Exchange Rate

JEL Classification: E51, C42, C33, E42, E43, F32

1 Mahjus Ekananda (m_ekananda@yahoo.com) is a lecturer and a researcher in Faculty of Economy and Bussines, University of Indonesia. 


\section{PENDAHULUAN}

Kajian mengenai dampak ekonomi makro terhadap NPL dan CAR telah banyak dilakukan oleh peneliti di berbagai negara dan juga Indonesia. Sebagian besar bank yang ada di Indonesia masih mengandalkan kredit sebagai pemasukan utama dalam membiayai operasionalnya. Kondisi perekonomian di Indonesia saat ini, kredit masih dipertahankan sebagai sumber pendapatan utama.

Pemberian kredit merupakan aktivitas bank yang paling utama dalam menghasilkan keuntungan, meskipun disisi lain risiko yang terbesar bank juga bersumber dari kredit yang bermasalah. Kualitas kredit bermasalah biasanya dicerminkan oleh rasio Non-Performing Loan (NPL). Islam dan Nishiyama (2016) menjelaskan bahwa semakin rendah rasio NPL maka akan semakin rendah tingkat kredit bermasalah. Rendahnya kredit bermasalah berarti mencerminkan semakin baik kondisi keuangan bank. Rasio Non-Performing Loan merupakan salah satu indikator dalam menilai kinerja fungsi bank.

Tingginya tingkat rasio NPL menunjukkan rendahnya tingkat kesehatan bank yang disebabkan oleh banyaknya permasalahan dalam pengelolaan kredit oleh bank. Rasio NPL yang tinggi sebagai refleksi ketidakmampuan sektor riil memperoleh keuntungan guna mengembalikan pinjamannya ke sektor perbankan. Dari sudut pandang ini, minimalisasi NPL sangat diperlukan untuk mempertahankan perekonomian yang stabil. Perubahan rasio NPL dan CAR dipengaruhi oleh banyak faktor internal dan eksternal.

Dari aspek internal, Altunbas (2000) menemukan hasil bahwa Net Interest Margin (NIM) berpengaruh positif terhadap NPL. Hughes and Mester (1993) dan Girardone (2004) menemukan bahwa ada hubungan positif antara NIM dengan non performing loan. Begitupun Misra dan Dhal (2010) menemukan bahwa LDR berpengaruh positif terhadap NPL. Faktor lainnya yaitu Aset bank, pada penelitian Misra dan Dhal (2010) mengemukakan bahwa Aset berpengaruh negatif terhadap NPL. Sedangkan penelitian yang dilakukan oleh Ranjan dan Dhal (2003) menyatakan bahwa terdapat pengaruh negatif antara Operational Assets (OCTA) dan Capital Adequacy Ratio (CAR) dengan NPL.

Adapun faktor penyebab pembiayaan bermasalah dari sisi eksternal yang direpresentasikan dengan Gross Domestic Product (GDP) dan inflasi. Salas dan Saurina (2002) menunjukkan adanya hubungan antara GDP dengan NPL. Hasil penelitian itu ditegaskan oleh Jimenez dan Saurina (2004) bahwa NPL dipengaruhi oleh GDP. Wu (2003) dalam penelitiannya menunjukkan bahwa pertumbuhan GDP di beberapa negara berkembang Asia Timur dan Asia Tenggara berpengaruh negatif signifikan terhadap kredit bermasalah (NPL). Penelitiannya menggunakan persamaan NPL yang dipengaruhi oleh pertumbuhan GDP, perubahan harga perumahan, primary landing rate dan rasio corporate real estate loans terhadap individual real estate loans. Hasilnya menunjukkan bahwa peningkatan $1 \%$ pertumbuhan GDP akan menurunkan rasio NPL sebesar $0.122 \%$. 
Jika dilihat dari studi empiris, bahwa faktor eksternal (Inflasi dan GDP) di atas ternyata berpengaruh pula terhadap NPL bank. Hasil penelitian Salas dan Saurina (2002) menunjukkan Nilai tukar berpengaruh positif terhadap NPL, dan menunjukkan bahwa inflasi berpengaruh negatif terhadap LDR. Sedangkan GDP yang merupakan jumlah produk yang dihasilkan masyarakat akan berdampak pada jumlah saving yang disimpan di bank. Simpanan itulah yang akan meningkatkan DPK dan otomatis meningkatkan likuiditas bank. Sehingga diprediksi GDP berpengaruh positif terhadap likuiditas. Salas and Saurina (2002) menemukan bahwa siklus bisnis mempengaruhi NPL ratio bank di Italia pada periode 1985 sampai 2002. Salas and Saurina (2002) mengestimasi dampak negatif contemporaneous GDP terhadap rasio NPL.

Analisis kredit perbankan di Indonesia dapat dilihat dari beberapa aspek, diantaranya kredit perbankan menurut sektor, menurut ukuran bank, ataupun menurut kepemilikan. Bank Indonesia (BI) mengklasifikasikan kegiatan usaha bank umum dalam empat kategori berdasarkan modal inti (Peraturan Bank Indonesia Nomor 14/26/PBI/2012 tanggal 27 Desember 2012 tentang Kegiatan Usaha dan Jaringan Kantor Berdasarkan Modal Inti Bank). BI memasukkan bank dengan modal inti mulai dari Rp100 miliar sampai di bawah Rp1 triliun dalam bank umum yang melaksanakan kelompok kegiatan usaha 1 (Buku 1), dari Rp1 triliun sampai di bawah Rp 5 triliun dalam Buku 2, dari Rp5 triliun hingga di bawah Rp30 triliun dalam Buku 3, sedangkan bank dengan modal inti Rp30 triliun atau lebih masuk dalam Buku 4.

Paper memiliki beberapa tujuan dan kontribusi untuk memecahkan masalah yang berkenaan dengan response NPL akibat adanya shock beberapa variabel ekonomi makro dan beberapa variabel internal bank dalam kelompok tertentu. Metode Panel VAR memungkinkan peneliti menganalisis keterkaitan antar bank, melakukan shock variabel ekonomi makro, kemudian dianalisis responsnya bank dalam kelompok tertentu. Panel VAR dapat menginvestigasi macrofinancial linkages (interaksi antara sektor keuangan dan ekonomi domestik/global), antara NPL dan variabel-variabel makroekonomi seperti BI Rate, pertumbuhan PDB, dan nilai tukar dan variabel makroekonomi lainnya. Gujarati (2004, hal 854) menyebutkan respon sebagai dampak total akibat adanya shock (impulse) dari variabel tertentu beberapa tahun yang akan datang. Pada uraian selanjutnya, istilah dampak pada analisis PVAR dimaksudkan sebagai dampak total antar variabel antar waktu (respon).

Bagian kedua dari paper ini mengulas teori dan literatur terkait hubungan antara kondisi ekonomi makro dengan kinerja industri perbankan. Bagian ini juga mengulas konstruksi model empiris yang akan diestimasi. Bagian ketiga mengulas data, teknik estimasi Panel Vector Autoregression, serta prosedur dan langkah penggunaanya. Bagian keempat menyajikan hasil perhitungan dan analisisnya, sementara bagian kelima menguraikan kesimpulan dan menjadi bagian penutup dari paper ini. 


\section{TEORI}

\subsection{Kinerja Bank dan Kondisi Ekonomi Makro}

Perkembangan NPL sangat erat berhubungan dengan perkembangan ekonomi makro. Beberapa penulis seperti Long and Plosser (1983) mengatakan bahwa dampak spillovers dari sektor finansial terhadap ekonomi adalah kunci untuk memahami recent global crisis. Studi ini menyebutkan bahwa faktor ekonomi makro dipandang memainkan peran penting dalam krisis perbankan. Penelitian di negara berkembang antara lain oleh Shu (2002) yang melakukan penelitian pada data kuartal 1995:1-2002:2, kredit bermasalah Hongkong memiliki hubungan negatif dengan pertumbuhan PDB, inflasi, dan kenaikan harga properti. Penelitian lain Farhan. (2012) menggunakan data kuesioner dari 201 bankir yang terlibat dalam penilaian kredit pada 10 bank di Pakistan. Dengan analisis korelasi dan regresi mereka menemukan kesesuaian persepsi bahwa kredit bermasalah (NPL) sektor perbankan Pakistan memiliki hubungan positif dengan tingkat suku bunga, krisis energi, pengangguran, inflasi, dan nilai tukar sementara pertumbuhan PDB memiliki hubungan negatif yang signifikan dengan kredit bermasalah dari perbankan Pakistan.

Paper ini mendisain penelitian melalui konsep mekanisme jalur suku bunga dan jalur nilai tukar dalam mempengaruhi kinerja perbankan. Louis, Vouldis \& Metaxas (2011) menjelaskan bahwa jalur suku bunga dilakukan oleh bank sentral untuk mempengaruhi suku bunga kredit dan deposito perbankan. Penurunan suku bunga BI Rate diharapkan segera diikuti dengan penurunan suku bunga kredit perbankan. Penelitian Gosh (2015) menjelaskan hubungan antara suku bunga dan nilai tukar sebagai determinan dari NPL dan kinerja bank.

Mekanisme kedua transmisi ini memerlukan waktu (time lag). Time lag masing-masing jalur bisa berbeda dengan yang lainnya. Jalur nilai tukar biasanya bekerja lebih cepat karena dampak perubahan suku bunga kepada nilai tukar bekerja sangat cepat. Kondisi sektor keuangan dan perbankan juga sangat berpengaruh pada kecepatan transmisi kebijakan moneter. Apabila perbankan melihat risiko perekonomian cukup tinggi, respon perbankan terhadap penurunan suku bunga BI rate biasanya sangat lambat.

Peneliti Canovaa dan Ciccarelli (2004) menjelaskan bahwa metode ekonometrika yang digunakan untuk analisis interdependensi diantaranya adalah model dynamic stochastic general equilibrium (DSGE) yang dibangun dari multi sector, multi market, dimana agen ekonomi pada keadaan optimal dengan kendala yang full specified. Model DSGE mampu menghasilkan estimasi parameter dan simulasi impulse akibat shock yang terjadi pada satu atau lebih variabel eksogen. Batasan dan asumsi yang utama harus dipenuhi adalah exact identification pada model ekonomi. Jumlah persamaan harus sama dengan jumlah parameter endogen. Shock disusun berdasarkan proses stochastic dan dinamisasi transmisi dampak antar variabel dihubungkan melalui Impulse Response Function (IRF).

Pendekatan alternatif lain yang berurusan dengan interdependensi individu ekonomi dan adanya faktor shock menggunakan IRF adalah GVAR dan panel VAR. Panel VAR menangkap 
dinamisasi interdependensi pada data menggunakan restriksi yang lebih sedikit. Identifikasi shock dapat ditransmisikan melalui reduced form kedalam persamaan structural melalui analisis impulse response. Struktural Panel VAR (SPVAR) dikembangkan kemudian untuk menanggulangi keterbatasan pada model struktural VAR standar. (lihat Faust dan Leeper (1997), Cooley dan Dweyer (1998)).

\subsection{Identifikasi Jalur Transmisi dan Spesifikasi Model Empiris}

Tujuan utama penelitian mendapatkan respon pada Variabel NIM, NPL dan CAR akibat adanya shock melalui suku bunga (IRD) dan adanya perubahan nilai tukar (DEPR).

Penelitian melakukan analisis pada 2 jenis model transmisi. Model pertama mengikuti konsep transmisi moneter melalui kebijakan suku bunga yang direspon oleh variabel NIM, NPL dan CAR. Variabel PVAR disusun menurut urutan Suku bunga domestik (IRD), Growth, NPL, NIM, dan CAR dengan variabel eksogen Aset Bank (ASSETS) dan Inflasi (INFLATION). Variabel eksogen pada model PVAR berperan variabel non dinamis, dalam arti variabel eksogen berperan sebagai kontrol (pengkondisi) lingkungan variabel dinamis yang diberlalukan dalam model.

$$
W_{i t}=\left[\begin{array}{c}
I R D_{t} \\
\text { Growth }_{t} \\
N P L_{i t} \\
N I M_{i t} \\
\text { CAR }_{i t}
\end{array}\right] \text { variabel exogen } X_{i t}=\left[\begin{array}{c}
\text { ASSET }_{i t} \\
\text { Inflation }_{t}
\end{array}\right]
$$

Dengan demikian transmisi pertama menjelaskan tranmisi kebijakan moneter melalui jalur suku bunga. Kebijakan moneter melalui pengendalian suku bunga diharapkan akan mempengaruhi iklim perekonomian Indonesia, yang selanjutnya akan meningkatkan pertumbuhan ekonomi. Pertumbuhan ekonomi yang terjadi disebabkan oleh situasi perekonomian sektoral yang produktif menghasilkan barang dan jasa. Perkembangan ekonomi yang tinggi akan meningkatkan kemampuan perusahaan mengembalikan pinjaman kepada bank sehingga rasio non performing loan (NPL) akan berkurang. Selanjutnya semakin banyak kredit lancar terbentuk yang menghasilkan bunga dan keuntungan sehingga net interest margin (NIM) bank meningkat. Peningkatan NIM akan meningkatkan keuntungan bank sehingga pada akhirnya akan meningkatkan CAR bank. Hal ini sesuai dengan isu terkini mengenai kebijakan Bank Indonesia menurunkan suku bunga pada akhir Oktober 2016.

Model kedua yaitu jalur nilai tukar, dimulai dari adanya depresiasi rupiah menyebabkan harga produk ekspor relatif lebih murah dibandingkan produk non domestik. Terjadi aliran ekspor, meningkatkan produktivitas perusahaan dan meningkatkan kemampuan beli masyarakat dan kemampuan mengembalikan pinjaman bank. Perubahan ini akan mengurangi rasio NPL. Selanjutnya semakin banyak kredit lancar terbentuk yang menghasilkan bunga dan keuntungan sehingga net interest margin (NIM) bank meningkat. Peningkatan NIM akan meningkatkan 
keuntungan bank sehingga pada akhirnya akan meningkatkan CAR bank. Struktur variabel PVAR disusun menurut urutan depresiasi nilai tukar Rupiah terhadap Dollar US (DEPR), Suku bunga domestik (IRD), NPL, NIM, dan CAR.

$$
W_{i t}=\left[\begin{array}{c}
D E P R_{t} \\
I R D_{t} \\
N P L_{i t} \\
N I M_{i t} \\
C A R_{i t}
\end{array}\right] \text { variabel exogen } X_{i t}=\left[\begin{array}{c}
\text { ASSET }_{i t} \\
\text { Inflation }_{t}
\end{array}\right]
$$

Perbedaan suku bunga yang semakin besar mendorong investor asing mengalir ke dalam instrumen-instrumen keuangan di Indonesia. Selanjutnya aliran modal masuk asing mendorong apresiasi nilai tukar Rupiah. Apresiasi Rupiah mengakibatkan harga barang impor lebih murah dan barang ekspor kita di luar negeri menjadi lebih mahal atau kurang kompetitif sehingga akan mendorong impor dan mengurangi ekspor. Turunnya net ekspor ini akan berdampak pada menurunnya pertumbuhan ekonomi dan kegiatan perekonomian. Variabel eksogen adalah Inflasi (INFLATION), Growth dan Asset Bank. Variabel eksogen pada model PVAR berperan variabel non dinamis, dalam arti variabel eksogen berperan sebagai kontrol (pengkondisi) lingkungan variabel dinamis yang diberlalukan dalam model.

Transmisi teoritis ini tentunya tidak terjadi bersamaan pada setiap bank dari waktu-ke waktu. Bank yang memiliki nasabah berkualitas, tidak sertamerta merespon peningkatan suku bunga dengan peningkatan NPL. Demikian juga sebaliknya peningkatan suku bunga tidak direspon dengan penurunan NIM dalam waktu bersamaan oleh setiap bank. Model PVAR dengan mempertimbangkan struktur fixed effect, urutan variabel, struktur lag, stationeritas data panel dan adanya variabel eksogen dalam model diharapkan dapat menghasilkan fenomena tertentu bank-bank di Indonesia yang dikelompokkan menurut BUKU.

\section{METODOLOGI}

\subsection{Sumber Data}

Populasi dalam penelitian ini adalah seluruh bank yang terdapat di Indonesia, sedangkan sampel yang digunakan dalam penelitian ini adalah beberapa bank yang memenuhi kecukupan/kelengkapan yang diperlukan untuk proses penghitungan ekonometrika panel VAR. Pengelompokan bank dibagi 4 menurut modal inti terdiri dari BUKU 1 sampai dengan BUKU 4. Data berasal dari seluruh bank dari tahun 2004 sampai dengan tahun 2014 (data semesteran) agar diperoleh informasi perilaku bank pada saat krisis keuangan tahun tahun 2008 (Stiglitz, 2010). Variabel ekonomi makro adalah sukubunga (IRD), dan perubahan nilai tukar riil (DEPR). Variabel internal bank adalah Net Interest Margin (NIM), Total Assets (ASSETS) dan Loan Deposit Ratio (LDR). Rasio NPL dihitung dari perbandingan jumlah kredit bermasalah terhadap total kredit. Aset Bank di hitung dalam logaritma natural. 


\begin{tabular}{|c|c|c|c|c|}
\hline \multicolumn{5}{|c|}{$\begin{array}{c}\text { Tabel } 1 . \\
\text { Deskripsi Statistik Kelompok Bank }\end{array}$} \\
\hline Keterangan & BUKU1 & BUKU2 & BUKU3 & BUKU4 \\
\hline Jumlah bank & 24 & 27 & 14 & 5 \\
\hline Rata-rata NPL (\%) & 3,279961 & 3,471268 & 4,108222 & 6,250600 \\
\hline Modal inti max (jutaan Rp) & $934.229,69$ & $4.682 .799,81$ & $26.218 .763,49$ & $100.631 .550,76$ \\
\hline Modal inti min (jutaan Rp) & $110.705,32$ & $1.046 .294,77$ & $5.352 .304,53$ & $31.818 .634,16$ \\
\hline Jumlah Kredit (jutaan Rp) & $2.475,44$ & $11.239,25$ & $58.152,94$ & $29.8744,1$ \\
\hline Rata-Rata CAR (\%) *) & 20,33 & 19,65 & 18,46 & 18,64 \\
\hline Rata-Rata NIM (\%) *) & 7,53 & 6,99 & 6,27 & 6,045 \\
\hline NIM Max (\%) & 19,19 & 16,25 & 15,47 & 12,25 \\
\hline Rata-Rata Aset (jutaan Rp) & $618.566,51$ & $2.424 .461,51$ & $17.624 .138,04$ & $138.321 .327,97$ \\
\hline
\end{tabular}

Data panel yang berhasil dikumpulkan sebanyak 70 buah bank dengan waktu observasi dari tahun 2004 sampai dengan akhir tahun 2014 agar diperoleh balanced panel yang diperlukan untuk estimasi PVAR. Deskripsi statistik kelompok bank dijelaskan pada Tabel 1. Jumlah bank terbesar pada kelompok BUKU 2 dengan Modal inti maksimum pada urutan ke tiga terbesar. Nilai rata-rata CAR terbesar pada BUKU 1, dan rata-rata CAR terkecil pada BUKU 3.

\subsection{Teknik Estimasi}

Paper ini menggunakan teknik estimasi Panel Vector Autoregression (PVAR). Beberapa aplikasi ekonometrika terkini belum menyediakan estimasi model PVAR sehingga penelitian ini menggunakan aplikasi terprogram. Holtz-Eakin (1988) mengemukakan konsep estimator PVAR yang dapat diselesaikan menggunakan GMM dan FGLS. Metode PVAR kemudian dikembangkan oleh Benes (2014) menggunakan Matlab untuk memproses interdependensi 3 ekonomi 3 negara. Rosen (1988) dan Love (2002) dan Love (2006) telah mengembangkan STATA programming untuk memproses PVAR. Hasil estimasi kedua program terdapat beberapa perbedaan mendasar. STATA programming menggunakan struktur data stacked yang biasa digunakan dalam STATA sedangkan Benes (2014) menggunakan struktur data unstacked. Estimator parameter pada STATA adalah GMM, sedangkan pada matlab adalah FGLS. Output yang dihasilkan program matlab lebih banyak memberikan informasi seperti nilai variance dekomposisi, nilai IRF untuk data panel atau data individu bank. Kelemahan teknis pada program matlab adalah karena susunan data unstacked mengharuskan pengguna mengubah program jika jumlah individu berubah. Penulis telah melakukan penelitian tidak terpublikasi dari Lembaga Penjamin Simpanan (LPS) menggunakan matlab dengan mengikuti prosedur Holtz-Eakin (1988).

Guna memahami perbedaan umum pada PVAR dibandingkan VAR, paper ini menjelaskan bangunan matriks data yang akan membantu peneliti melakukan analisis IRF dan Variance Decomposition. Perbedaan yang mendasar antara PVAR dan VAR terletak pada struktur data 
yang mengadopsi perilaku antar individu sekaligus perilaku dinamis antar variabel. PVAR yang digunakan menggunakan konsep estimator yang dikemukakan oleh Holtz-Eakin (1988). Dalam kasus panel VAR, sebuah data terdiri dari $\mathrm{i}=1,2, \ldots, \mathrm{N}$ individu. Dimana setiap individu memiliki $\mathrm{t}=1,2,3, \ldots$ T periode. Jika matriks $\mathrm{W}$ terdiri dari 3 variabel $y_{i t^{\prime}} z_{i t}$ dan $p_{i t^{\prime}}$ serta secara ringkas model PVAR(1) dinyatakan sebagai

$$
W_{i t}=\beta_{0}+\sum_{l=1}^{m+1} \beta_{l t} W_{i t-1}+\varepsilon_{i t}
$$

Karena W merupakan vektor yang terdiri dari 3 variabel, maka persamaan PVAR terdiri dari 3 buah persamaan. Persamaan pertama

$$
y_{i t}=\beta_{10}+\beta_{11} y_{i t-1}+\beta_{12} z_{i t-1}+\alpha_{11} p_{i t-1}+\varepsilon_{y, i t}
$$

Dimana variabel dependen berupa vektor

$$
y_{i t}=\left[\begin{array}{c}
y_{1, m+2} \\
\cdots \\
y_{N, m+2} \\
y_{1, m+3} \\
\cdots \\
y_{N, m+3} \\
\cdots \\
y_{1, T} \\
y_{N, T}
\end{array}\right]_{[T-(m+2)+1] N x 1}
$$

$$
y_{i t-1}=\left[\begin{array}{c}
y_{1, m+1} \\
\cdots \\
y_{N, m+1} \\
y_{1, m+2} \\
\cdots \\
y_{N, m+2} \\
\cdots \\
y_{1, T-1} \\
y_{N, T-1}
\end{array}\right]_{[T-(m+2)+1] N x 1}
$$

Variabel $y_{i t}$ disusun sebagai vektor kolom yang terdiri dari individu pertama sampai individu $\mathrm{N}$ pada tahun ke $\mathrm{m}+1$, Kemudian susunan kolom berulang dibawahnya untuk individu pertama sampai individu $\mathrm{N}$ pada tahun ke $\mathrm{m}+3$ dan seterusnya individu pertama sampai individu $\mathrm{N}$ pada tahun ke T. Dengan demikian vektor kolom memiliki dimensi $[\mathrm{T}-(\mathrm{m}+2)+1] \mathrm{Nx} 1$. Untuk vektor $y_{t-1}$ disusun dengan cara yang sama tetapi data dimulai dari waktu ke $m+1$ sampai $T-1$. Variabel $\mathrm{m}$ adalah jumlah lag yang diinginkan. Variabel lain yaitu $z_{i t}$ dan $p_{i t}$ disusun dengan cara yang sama tetapi data dimulai dari waktu ke $\mathrm{m}+1$ sampai $\mathrm{T}-1$.

Dari uraian matriks (3) kita dapat dimengerti bahwa variabel dependen disusun berurutan sesuai dengan individu, kemudian berulang dengan waktu berbeda. Matriks disebelah kanan persamaan pertama (independen) dinotasikan sebagai $W y_{i t-1}$. Matriks (4) adalah blok diagonal yang terdiri dari matriks $w$. 


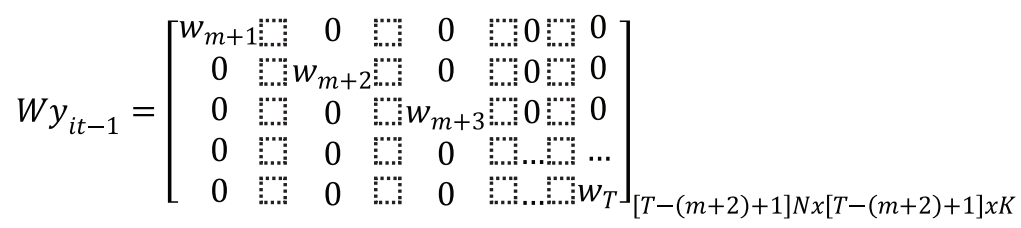

Matriks $w$ terdiri data lag variabel $y_{i t^{\prime}} p_{i t}$ dan $z_{i t^{*}}$ yaitu

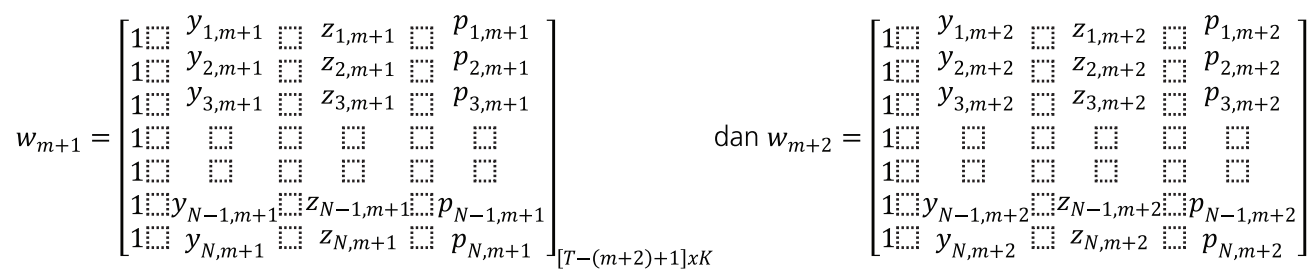

seterusnya sampai

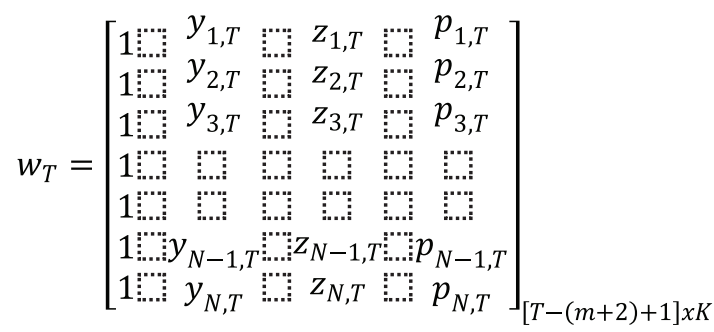

Struktur persamaan pertama (2) diterapkan pula untuk persamaan kedua $\left(z_{i t}\right)$ yaitu

$z_{i t}=\beta_{20}+\beta_{21} y_{i t-1}+\beta_{22} z_{i t-1}+\alpha_{21} p_{i t-1}+\varepsilon_{z, i t}$

persamaan ke tiga $\left(p_{i t}\right)$

$p_{i t}=\beta_{30}+\beta_{31} y_{i t-1}+\beta_{32} z_{i t-1}+\alpha_{31} p_{i t-1}+\varepsilon_{p, i t}$

vektor variabel dependen untuk persamaan (6) dan (7) adalah

$z_{i t}=\left[\begin{array}{c}z_{1, m+1} \\ \cdots \\ z_{N, m+1} \\ z_{1, m+2} \\ \cdots \\ z_{N, m+2} \\ \cdots \\ z_{1, T-1} \\ z_{N, T-1}\end{array}\right]_{[T-(m+2)+1] N x 1} \quad p_{i t}=\left[\begin{array}{c}p_{1, m+1} \\ \cdots \\ p_{N, m+1} \\ p_{1, m+2} \\ \cdots \\ p_{N, m+2} \\ \cdots \\ p_{1, T-1} \\ p_{N, T-1}\end{array}\right]$ 
Variabel independen persamaan (6) dan (7) memiliki struktur independen yang sama dengan persamaan (4) dinotasikan sebagai $W z_{i t-1}$ dan $W p_{i t-1}$, sehingga

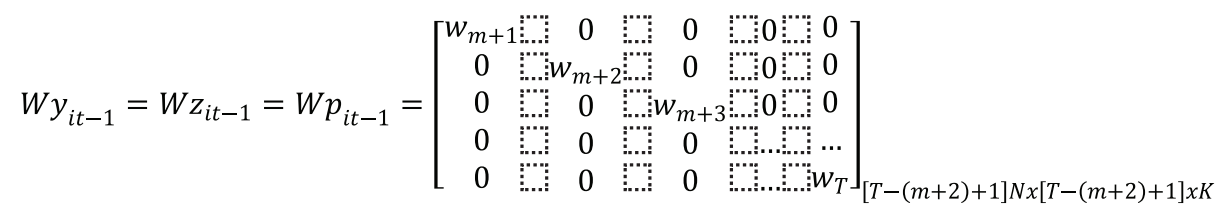

Rangkaian semua vektor $W_{i t}$ adalah dependen dan vektor $W_{i t-1}$ adalah independen, yaitu

$$
W_{i t}=\left[\begin{array}{l}
y_{i t} \\
z_{i t} \\
p_{i t}
\end{array}\right]_{[T-(m+2)+1] M x N x 1} \operatorname{dan} W_{i t-1}=\left[\begin{array}{ccc}
W y_{i t-1} & \ldots & \ldots \\
\hdashline & W z_{i t-1} & \ldots \\
\hdashline & \ldots & W p_{i t-1}
\end{array}\right]_{[T-(m+2)+1] 3 N x[T-(m+2)+1] M x K}
$$

Notasi M adalah jumlah variabel sebanyak 3. Greene (2008) menjelaskan bahwa parameter $\beta$ dapat diselesaikan dengan :

$$
\widehat{\beta}=\left(W_{i t-1}^{\prime} V^{-1} W_{i t-1}\right)^{-1} W_{i t-1}^{\prime} V^{-1} W_{i t}
$$

Estimator unbiased untuk $\widehat{\beta}$ adalah

$$
\widehat{\beta}=\left(W_{i t-1}^{\prime} V^{-1} W_{i t-1}\right)^{-1} W_{i t-1}^{\prime} V^{-1} Y_{i t}=\left(\sum_{i=1}^{n} \sum_{j=1}^{n} \sigma^{i j} W_{i}^{\prime}\right)^{-1}\left(W_{j} \sum_{i=1}^{n} \sum_{j=1}^{n} \sigma^{i j} W_{i}^{\prime} Y_{j}\right)
$$

Dimana matriks $V$ adalah matriks varian kovarian residual antara persamaan $y_{i t^{\prime}} z_{i t}$ dan $p_{i t}$. Korelasi antar waktu dan matriks error menjadi:

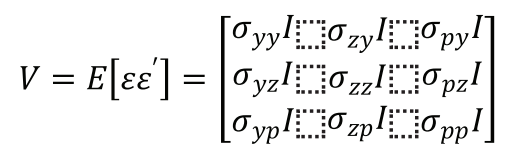

Impulse response function sebagaimana proses VAR standar dapat dibentuk sesudah proses estimasi. Ringkasnya, PVAR diiterasi dengan kondisi parameter PVAR stabil. Model PVAR diiterasi akan membentuk 3 bagian yaitu unsur rata-rata $\mu$, matriks parameter terestimasi $A$ dan $e_{i t-j}$ pure innovation atau dalam bentuk forecast shock $\varepsilon_{i t}$ untuk memperhatikan adanya dampak contemporaneous pada PVAR (Enders, 2009).

$$
W_{i t}=\mu+\sum_{j=1}^{\infty} A_{1}^{t} e_{i t-j}=\mu+\sum_{j=1}^{\infty} \phi_{j} \varepsilon_{i t-j}
$$


Jika dimisalkan, PVAR terdiri dari 2 variabel $(M=2)$, dan $\beta$ adalah parameter teresimasi PVAR dan $\alpha$ adalah parameter matriks parameter contemporaneous, maka menghasilkan bentuk IRF sebagai berikut.

$$
\left[\begin{array}{l}
y_{i t} \\
z_{i t}
\end{array}\right]=\left[\begin{array}{l}
\bar{y}_{i t} \\
\bar{z}_{i t}
\end{array}\right]+\sum_{i=1}^{\infty}\left[\begin{array}{ll}
\beta_{11} & \beta_{12} \\
\beta_{21} & \beta_{22}
\end{array}\right]^{i} \frac{1}{\left(1-\alpha_{12} \alpha_{21}\right)}\left[\begin{array}{cc}
1 & -\alpha_{12} \\
-\alpha_{21} & 1
\end{array}\right]\left[\begin{array}{l}
\varepsilon_{y, i t-1} \\
\varepsilon_{z, i t-1}
\end{array}\right]
$$

Shock yang terjadi pada ruas kanan $\varepsilon$ akan menghasilkan perubahan dinamis pada variable pada ruas kiri.

Paper ini disusun dengan menerapkan struktur ortogonalisasi Cholesky pada IRF agar diperoleh dampak transmisi antar variabel pada saat terjadinya shock (contemporaneous impact). Paper ini menganalisis impulse yang terjadi pada saat yang bersamaan dengan saat gangguan terjadi dan menganalisis dinamisasi yang terjadi sesudah gangguan terjadi beberapa periode yang akan datang (Hamilton, 1994). Dampak contemporaneous dengan struktur ortogonalisasi Cholesky menjadi

$$
\frac{1}{\left(1-\alpha_{12} \alpha_{21}\right)}\left[\begin{array}{cc}
1 & -\alpha_{12} \\
-\alpha_{21} & 1
\end{array}\right] \text { atau menjadi }\left[\begin{array}{cc}
1 & 0 \\
-\alpha_{21} & 1
\end{array}\right]
$$

Penerapan ortogonalisasi Cholesky membuat susunan urutan variabel (orde) akan sangat menentukan hasil analisis IRF. Model PVAR yang digunakan juga memperhatikan adanya variabel eksogen yang agar diperoleh lingkungan dinamis yang sesuai dengan lingkungan ekonomi perbankan.

Transmisi dan urutan (order) menggunakan metode Cholesky akan menghasilkan dua macam analisis, yaitu analisis respon yang terjadi 1) seketika (contemporaneous) dan 2) respon yang terjadi pada periode berikutnya sesudah impulse terjadi. Variabel yang disusun untuk membentuk urutan pada struktur ortogonalisasi cholesky menunjukkan dampak total antar variabel saat terjadinya shock. Pada analisis selanjutnya, istilah dampak pada analisis PVAR dimaksudkan sebagai dampak total antar waktu (respon).

Respon yang terjadi pada periode selanjutnya akan merekam dampak gabungan antar waktu. Oleh sebab itu, respon pada periode selanjutnya sangat bergantung pada struktur lag, stationeritas variabel dan peran dari variabel eksogen pada model VAR. Penggunaan model Fixed Effect pada PVAR diharapkan mampu untuk menangkap unobserved variabel bank.

Estimasi PVAR mengadopsi prototipe program PVAR yang dibuat oleh Love (2002) menggunakan STATA programing. Love (2002) juga menerapkan struktur matriks yang dikemukakan oleh Holtz-Eakin (1988) untuk menaksir parameter $\beta$. Hasil estimasi $\beta$ merupakan parameter yang mengumpulkan semua informasi yang didapat dari data ekonomi makro dan 
data internal bank yang disusun menurut struktur data yang mempertimbangkan adanya perilaku bank menurut kelompok ukuran pinjaman (LOAN) selama waktu observasi. Parameter $\beta$ sebagai parameter yang menjelaskan dampak dinamis bank antar waktu.

Dalam penelitian ini diasumsikan bahwa perbankan hanya mempertimbangkan informasi dari 1 periode sebelumnya. Dengan demikian penelitian ini menggunakan PVAR(1). Melalui penjelasan tadi maka kita dapat memahami bahwa dampak pada periode 1 adalah contemporaneous response, sedangkan pada lag ke 2,3, dan selanjutnya adalah respon yang telah memgalami interaksi antar bank dan antar waktu. Sesuai aturan standar, shock pada variabel ekonomi makro dilakukan sebesar $1 \%$ dimaksudkan untuk memudahkan penghitungan respon yang terjadi pada variabel NPL dan LOAN yang diamati pada penelitian ini. Jika pada saat itu nilai tukar pada tingkat Rp. $10.000 /$ S \$, maka shock sebesar 1\% menunjukkan terjadi peningkatan nilai tukar menjadi Rp. 10.100 /US\$ dalam waktu yang singkat. Jika pada grafik, nilai respon NPL 0.8 berarti terjadi respon sebesar $0.8 \%$ akibat dari shock pada variabel ekonomi makro sebesar $1 \%$. Jika diandaikan terjadi shock sebesar $2.5 \%$ pada nilai tukar, maka terjadi respon NPL 2\% $(0.8 \% \times 2.5)$.

Meskipun dalam beberapa penelitian lain shock dihitung menggunakan 1 unit (perubahan sesuai dengan satuan dari data) atau satu standar deviasi (sebesar simpangan dari data historis), penelitian ini menggunakan shock dalam persentase agar sesuai dengan analisis elastisitas yang telah dijelaskan pada analisis data panel sebelumnya. Seluruh shock pada variabel ekonomi makro yang dijelaskan dalam penelitian ini diasumsikan terjadi sebesar $1 \%$. Shock positif menunjukkan peningkatan sedangkan shock negatif menunjukkan penurunan dalam waktu singkat.

\subsection{Pengujian Akar Unit Panel}

Interaksi data berbagai bank dalam rentang waktu yang panjang dapat menimbulkan kecurigaan adanya hubungan kointegrasi antar data bank selama waktu observasi (Pedroni, 2000). Hubungan kointegrasi menjadi penting karena akan akan menentukan metode analisis dan interpretasi hasil penelitian (Breitung dan Pesaran, 2008). Perkembangan ilmu ekonometrika terkini telah berkembang dan menyiratkan perlunya melakukan uji akar unit panel pada analisis dinamisasi data panel (Pesaran, 2007). Berbagai literatur memulai analisis dengan melakukan pengujian akar unit panel (Kao, Chiang, and Chen, 1999). Terdapat beberapa metode pengujian untuk mengetahui keberadaan akar unit. Hadri (2000) dan Pesaran (2004) mengajukan pengujian akar unit panel yang dikembangkan dengan adanya asumsi cross-sectional independence diantara data individu. Terdapat banyak metode pengujian yang disediakan oleh aplikasi Eviews yaitu metode Levin, Lin and Chu (2002), Breitung (2000), Im, Pesaran dan Shin (2003), Fisher-type tests menggunakan ADF and PP tests-Maddala dan Wu (1999), Choi (2001), Hadri (2000) dan Ekananda (2016). Untuk menguji adanya ketergantungan cross-sectional antar data, penelitan ini menerapkan pengujian ADF - Fisher Chi-square menurut Maddala and Wu (1999). 
Hasil uji panel unit root disesuaikan dengan model PVAR yang digunakan. Variabel yang terlibat yaitu Growth, NIM, NPL, CAR dengan variabel eksogen suku bunga domestic (IRD), depresiasi nilai tukar Rp terhadap Dollar US (DEPR) dan Inflasi (INFLATION). Variabel ini berlaku untuk semua kelompok bank, Buku-1 sampai dengan buku-4. Buku 1 yang terdiri dari kelompok bank dengan modal inti paling kecil menunjukkan semua data pada tingkat level menolak $\mathrm{H}_{0}$, yaitu kondisi stasioner. Bank dalam kelompok ini mempunyai anggota paling banyak dan sangat beragam. Pengujian unit root akan mengindikasikan apakah ada stationeritas pada data dalam kelompok tertentu yang saling berhubungan (Ekananda, 2014).

\begin{tabular}{|c|c|c|c|c|}
\hline \multicolumn{5}{|c|}{$\begin{array}{c}\text { Tabel } 2 . \\
\text { Uji Panel Unit Root BUKU } 1 \text { sampai BUKU } 4\end{array}$} \\
\hline \multirow{2}{*}{ Variabel } & \multicolumn{4}{|c|}{ ADF - Fisher Chi-square } \\
\hline & BUKU 1 & BUKU 2 & BUKU 3 & BUKU 4 \\
\hline Aset & 88,6978 & 176,486 & 293,928 & 0,09772 \\
\hline CAR & 103,654 & 145,165 & 65,4372 & 16,4965 \\
\hline Depr & 367,831 & 399,149 & 206,434 & 73,5642 \\
\hline Growth & 170,672 & 161,441 & 87,7752 & 28,3638 \\
\hline Inflation & 207,372 & 229,842 & 115,312 & 43,9922 \\
\hline IRD & 86,7986 & 97,6484 & 50,6325 & 18,0830 \\
\hline NIM & 128,730 & 174,376 & 70,5783 & 32,0915 \\
\hline NPL & 189,087 & 471,771 & 92,1696 & 81,7557 \\
\hline
\end{tabular}

Hasil yang serupa diperlihatkan pada pengujian unit root bank dalam kelompok Buku 2. Jumlah bank yang termasuk pada kelompok ini sebanyak 27 buah. Jumlahnya hampir sama dengan kelompok bank dengan modal inti terkecil. Hasil pengujian menunjukkan hasil dimana semua data dalam kondisi penolakan terhadap $\mathrm{H}_{0}$, berarti menunjukkan kondisi stasioner. Hasil uji stationeritas data panel menunjukkan bahwa semua data dalam kelompok ini menunjukkan adanya hubungan jangka panjang yang saling beriringan (co movement) dan situasi adanya hubungan ketergantungan linier (co integration). Variabel Bank dalam kelompok Buku 3 memperlihatkan perilaku yang sama, dimana semua variabel yang akan digunakan statrsioner pada tingkat level. Jumlah bank pada kelompok ini sebagian besar bank swasta nasional yang telah lama berdiri. Sebagian besar bank memiliki jumlah cabang yangbanyak dan tersebat keseluruh provinsi di Indonesia. Penggunakan data pada tingkat level akan dilakukan pada model 1 dan model 2 sebagaimana halnya dilakukan pada kelompok Buku lainnya.

Buku 4 hanya terdiri dari 6 bank terbesar dalam jumlah modal inti. Sebagian besar adalah bank milik pemerintah. Hanya variabel aset yang tidak stasioner. Dengan demikian, strategi estimasi khusus pada kelompok ini adalah mengestimasi aset pada tingkat differens.

Langkah berikutnya adalah pengujian ko-integrasi panel untuk menjelaskan adanya hubungan jangka panjang antara variabel individu bank yang digunakan. Pengujian ko- 
integrasi pada data panel mengikuti prosedur aplikasi Eviews, dimana data disusunan dalam bentuk stacked, kemudian variabel yang terlibat dalam model dikelompokkan sebagai Group. Pengujian menggunakan metode Maddala and Wu (1999). Data yang dikelompokkan adalah NPL, GROWTH, DEPRESIASI, NIM, ASSETL, CAR, IRD dan INFLATION. Tipe pengujian memakai Kao Residual Cointegration Test (Kao, 2000) Trend assumption: No deterministic trend, Userspecified lag length: 1, Newey-West automatic bandwidth selection and Bartlett kernel. Hasil pengujian ko-ingreasi sebagai berikut.

\begin{tabular}{l|c|c|}
\multicolumn{3}{c}{ Tabel 3. } \\
Koinetgrasi Panel \\
Kelompok BUKU & t-Statistic & \\
BUKU 1 & -5.326729 & Prob. \\
BUKU 2 & -13.81330 & 0.0000 \\
BUKU 3 & -14.13320 & 0.0000 \\
BUKU 4 & -2.297114 & 0.0000 \\
& & 0.0108
\end{tabular}

Berdasarkan pada uji akar unit dan uji ko-integrasi, jelas bahwa estimasi PVAR menggunakan data pada tingkat level karena uji akar unit memperlihatkan stationeritas pada tingkat level dan terdapat hubungan ko-integrasi pada kelompok data pada tingkat level.

\section{HASIL DAN ANALISIS}

Analisis data panel menggunakan PVAR dengan mempertimbangkan struktur fixed effect, urutan variabel, struktur lag, stationeritas data panel dan adanya variabel eksogen dalam model. Aplikasi menggunakan programming STATA yang dikembangkan oleh Love (2002) dan Love (2006). Semua komponen ini dipertimbangkan agar dapat mengungkap respon pada variabel perbankan akibat adanya shock (impulse) variabel pertumbuhan ekonomi dan variabel interest rate domestik dibandingkan menggunakan VAR standar. Untuk itulah penelitian ini berupaya menggunakan semua faktor pembentuk model PVAR secara lengkap.

Model transmisi pertama menjelaskan respon pada beberapa variabel internal bank NPL, NIM dan CAR akibat adanya impulse pada suku bunga domestik (IRD). Kebijakan moneter diharapkan akan memberikan stimulus meningkatkan produktifitas perekonomian dalam menghasilkan barang dan jasa. Semua sektor akan meningkatkan produksinya membawa dampak positif bagi kemampuan kreditur mengembalikan pinjaman kepada bank.

Berikut ini adalah hasil visualisasi (grafik) dinamis respon dari beberapa variabel internal bank akibat impulse (shock) dari beberapa variabel ekonomi makro yaitu suku bunga domestik (IRD) dan Depresiasi (DEPR). Jika kita meninjau impulse response function (IRF) pada NIM, NPL dan CAR, maka hal ini menunjukkan adanya dampak gabungan antara parameter yang 
dinamis (dampak antara variabel antar waktu), adanya dampak yang tidak langsung (adanya variabel lain yang memediasi dampak antara variabel ekonomi makro dengan variabel internal bank), adanya shock pada satu variabel yang memicu perubahan pada variabel internal bank dan iterasi antara parameter PVAR untuk menghasilkan respon pada waktu-waktu tertentu.

Peningkatan suku bunga domestik umumnya selalu direspon positif peningkatan suku bunga kredit. Suku bunga deposito biasanya tidak segera merespon peningkatan ini. Respon ini terjadi pada bank yang lebih intensif mengharapkan keuntungan melalui interest base income. Bank dengan modal inti lebih kecil umumnya mengandalkan keuntungan melalui interest base income. Bank dengan modal inti kecil umumnya belum memiliki produk andalan yang dikenal luas dan diminati masyarakan selain produk yang mengandalkan jasa bunga. Bank dengan modal inti besar umumnya telah lama berdiri dan memiliki pangsa pasar yang luas. Bank ini memiliki cukup banyak produk-produk berbeda (differentiated product). Dari produk ini mereka mengandalkan keuntungan melalui fee based income.

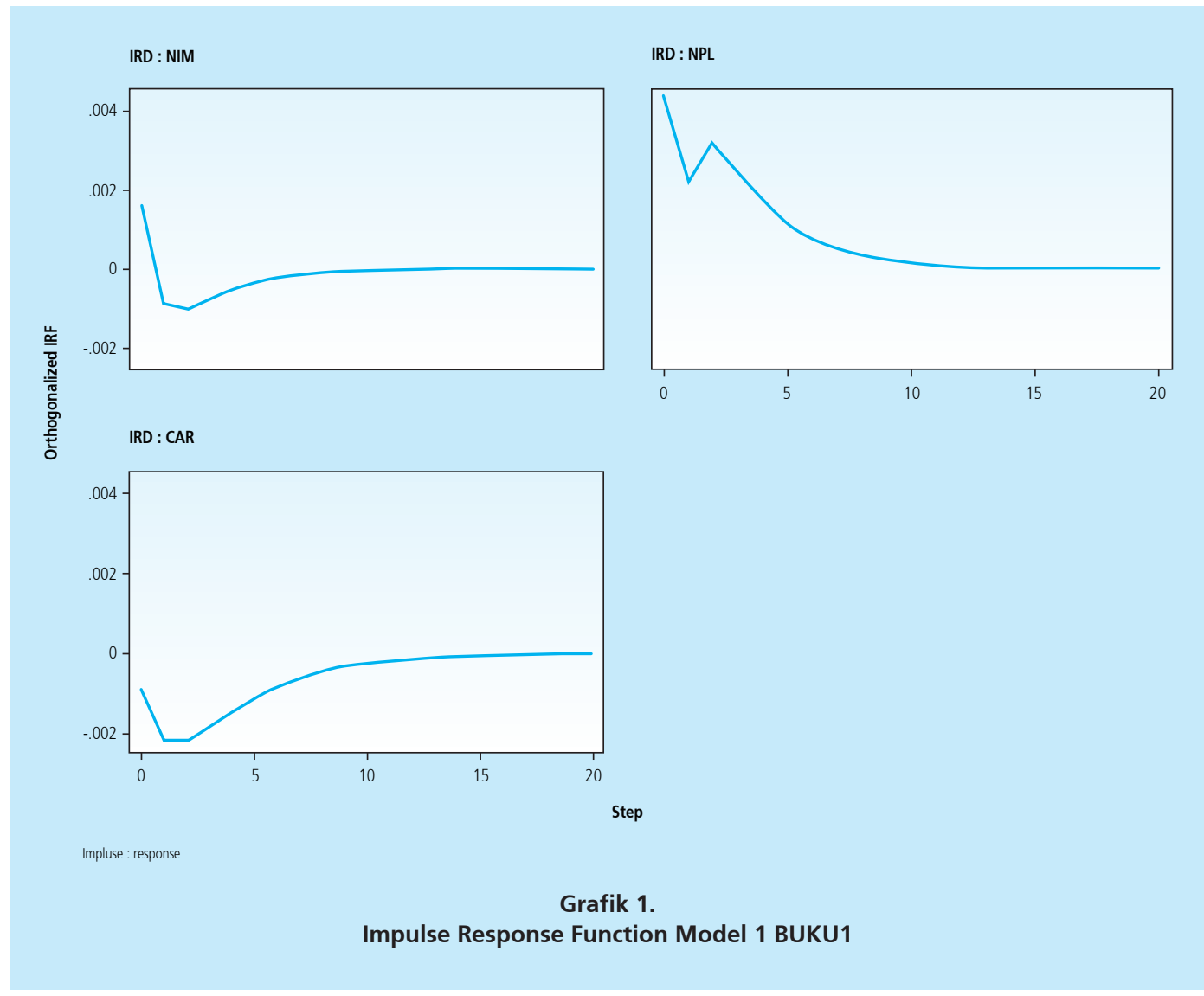


Grafik 1 menjelaskan Impulse Response Function bank-bank pada kelompok modal inti mulai dari Rp100 miliar sampai di bawah Rp1 triliun. NPL merespon positif pada saat terjadinya peningkatan suku bunga (contemporaneous). Bank dengan modal inti kecil akan merespon positif dengan meningkatkan suku bunga pinjaman, akibatnya terjadi peningkatan NPL. Respon NPL pada periode selanjutnya semakin kecil. Hal ini menunjukkan dampak dari peningkatan suku bunga semakin kecil.

NIM merespon negatif peningkatan suku bunga domestik akibat semakin tingginya NPL. Rata-rata NIM bank-bank ini paling besar diantara kelompok lainnya sebesar 7.526\%. NIM diawal periode menunjukkan respon positif, namun segera merespon negatif pada periode selanjutnya. Respon NIM diperiode ke kedua sampai selanjutnya menunjukkan respon NIM akibat perubahan variabel-variabel dari periode sebelumnya. Dinamisasi ini saling berkaitan (interdependence) antar variabel yang digunakan dalam model. Penurunan NIM akan menurunkan keuntungan dan akan menurunkan penambahan modal bank. CAR merespon negatif semua perubahan yang terjadi pada variabel Suku bunga domestik, NPL dan NIM.

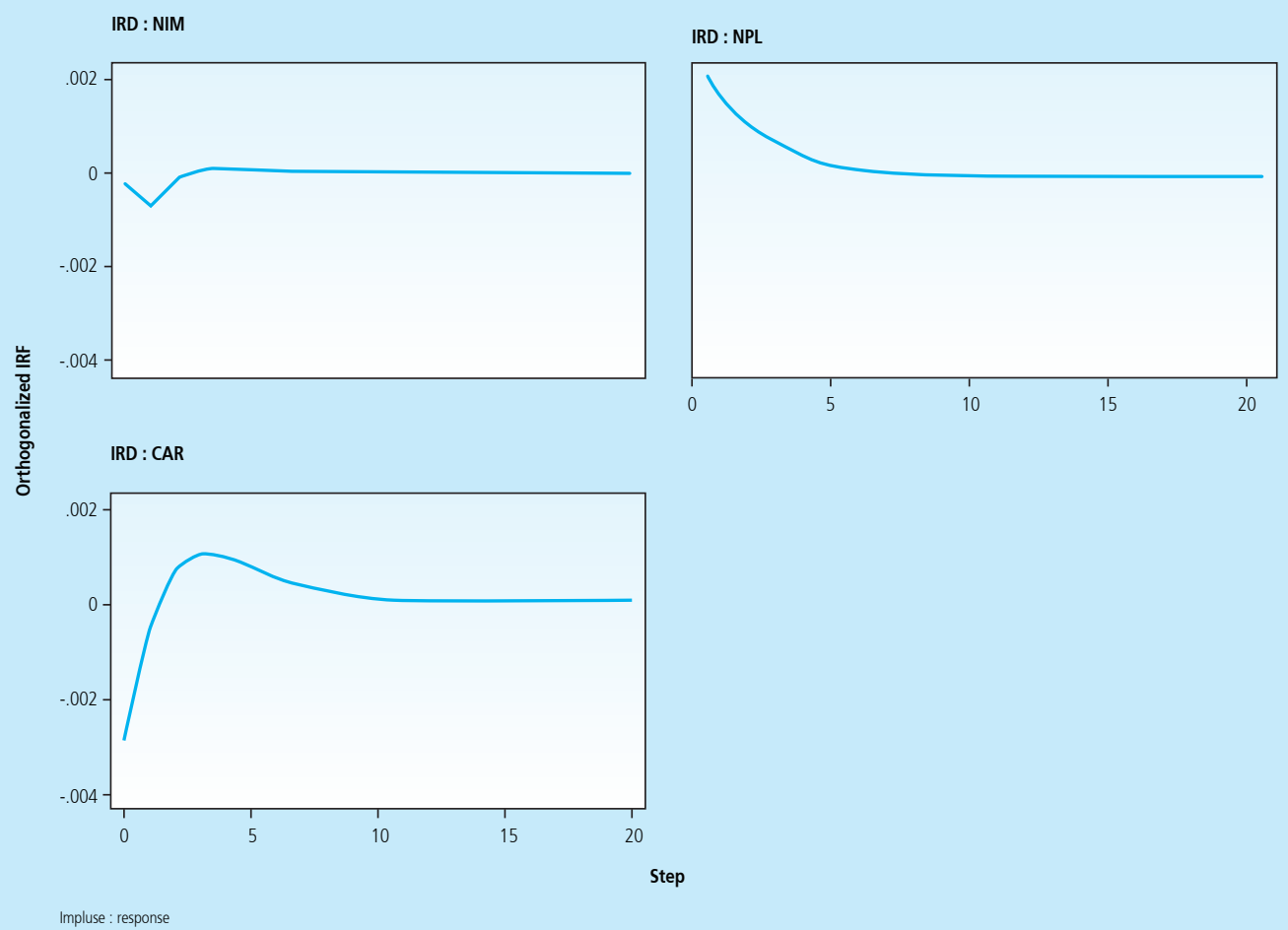

Grafik 2.

Impulse Response Function Model 1 BUKU2 
Grafik 2 menjelaskan Impulse Response Function bank-bank pada kelompok modal inti mulai dari Rp1 triliun sampai di bawah Rp 5 triliun (BUKU 2). Dilihat dari jumlah modal inti, bank yang tergolong pada BUKU 2 memiliki kemampuan permodalan yang lebih besar dibandingkan BUKU 1. Peningkatan suku bunga domestik membuat Bank pada kelompok ini merespon positif dengan meningkatkan suku bunga pinjaman, akibatnya terjadi peningkatan NPL. Respon NPL pada periode selanjutnya semakin kecil. Hal ini menunjukkan dampak dari peningkatan suku bunga semakin kecil. NIM merespon negatif peningkatan suku bunga domestik akibat semakin tingginya NPL. NIM diawal periode langsung menunjukkan respon negatif dan kemudian menghilang pada periode selanjutnya. Mirip dengan penjelasan sebelumnya, penurunan NIM akan menurunkan keuntungan dan akan menurunkan penambahan modal bank. CAR merespon negatif semua perubahan yang terjadi pada variabel Suku bunga domestik, NPL dan NIM.

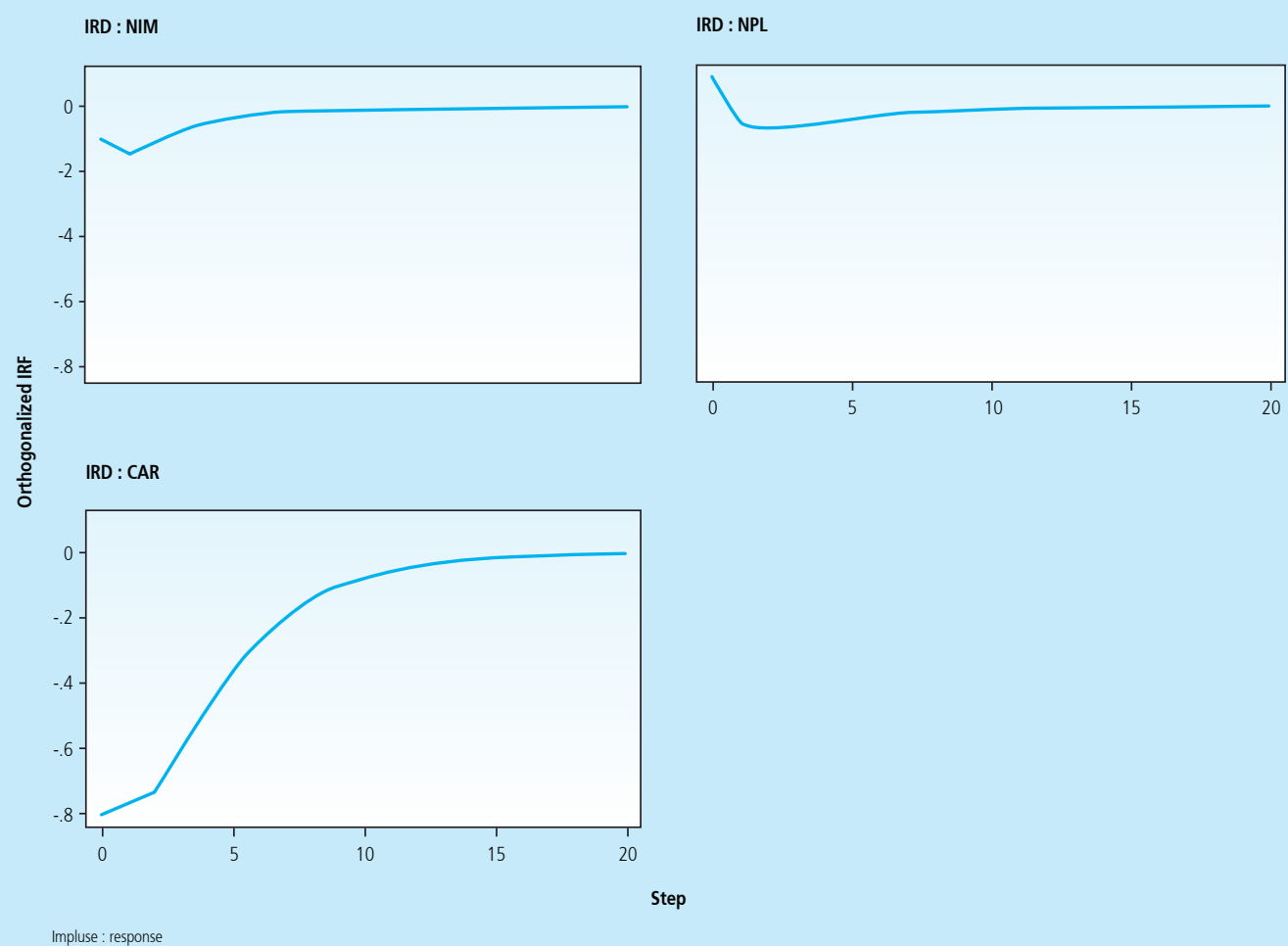

Grafik 3.

Impulse Response Function Model 1 BUKU3 
Grafik 3 menjelaskan Impulse Response Function bank-bank pada kelompok modal inti mulai dari Rp5 triliun hingga di bawah Rp30 triliun (BUKU 3). Dilihat dari jumlah modal inti, bank yang tergolong pada BUKU 3 memiliki kemampuan permodalan yang cuku besar. Namun NIM dan CAR lebih kecil dibandingkan kelompok sebelumnya. Rata-rata NPL BUKU 3 ternyata lebih besar dibandingkan BUKU 1 dan BUKU 2. Peningkatan suku bunga domestik membuat Bank pada kelompok ini langsung merespon positif NPL, namun NPL merespon negatif peningkatan suku bunga domestik pada periode ke 2 dan selanjutnya. Respon negatif menunjukkan terjadi penurunan NPL. NIM merespon negatif pada awal periode, kemudian respon akan hilang pada periode selanjutnya. CAR merespon negatif semua perubahan yang terjadi pada variabel Suku bunga domestik, NPL dan NIM. Bank pada BUKU 3 melakukan penyesuaian peningkatan CAR lambat sampai pada tingkat dimana tidak lagi ada respon.

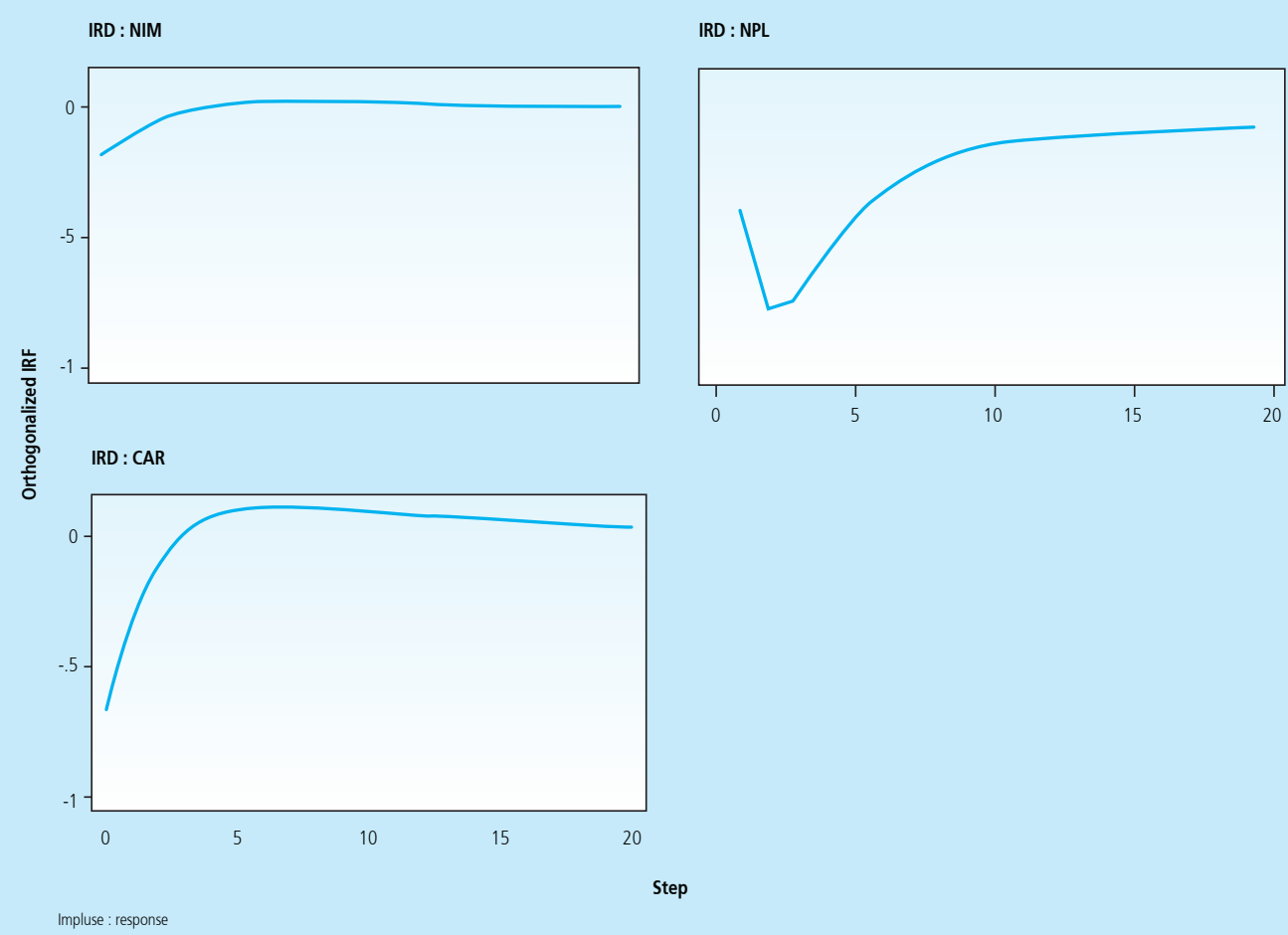

Grafik 4.

Impulse Response Function Model 1 BUKU4

Grafik 4 menjelaskan Impulse Response Function bank-bank pada kelompok modal inti diatas Rp 30 triliun (BUKU 4). Dilihat dari jumlah modal inti, bank yang tergolong pada BUKU 3 memiliki kemampuan permodalan yang cukup besar. Namun NIM dan CAR paling kecil 
dibandingkan semua kelompok. Rata-rata NPL BUKU 4 ternyata paling besar dibandingkan semua kelompok lainnya. Peningkatan suku bunga domestik membuat Bank pada kelompok ini langsung merespon positif NPL, namun NPL merespon negatif peningkatan suku bunga domestik pada periode ke 2 dan selanjutnya. Respon negatif menunjukkan terjadi penurunan NPL. NIM merespon negatif pada awal periode, kemudian respon akan hilang pada periode selanjutnya. CAR merespon negatif semua perubahan yang terjadi pada variabel Suku bunga domestik, NPL dan NIM. Bank pada BUKU 3 melakukan penyesuaian peningkatan CAR lebih cepat sampai pada tingkat dimana tidak lagi ada respon.

Paper ini membahas pula IRP akibat dari impulse depresiasi nilai tukar yang direspon variabel NPL, NIM dan CAR. Salah satu tugas utama Bank Indonesia menstabilkan harga melalui pengendalian nilai tukar. Depresiasi akan menyebabkan harga aset semakin tinggi, suku bunga tinggi dan selanjutnya akan kemampuan masyarakat mengkonsumsi barang. Bagi agen ekonomi yang memiliki pinjaman di bank akan menurunkan kemampuan pengembalian kredit, karena biaya operasi semakin besar.

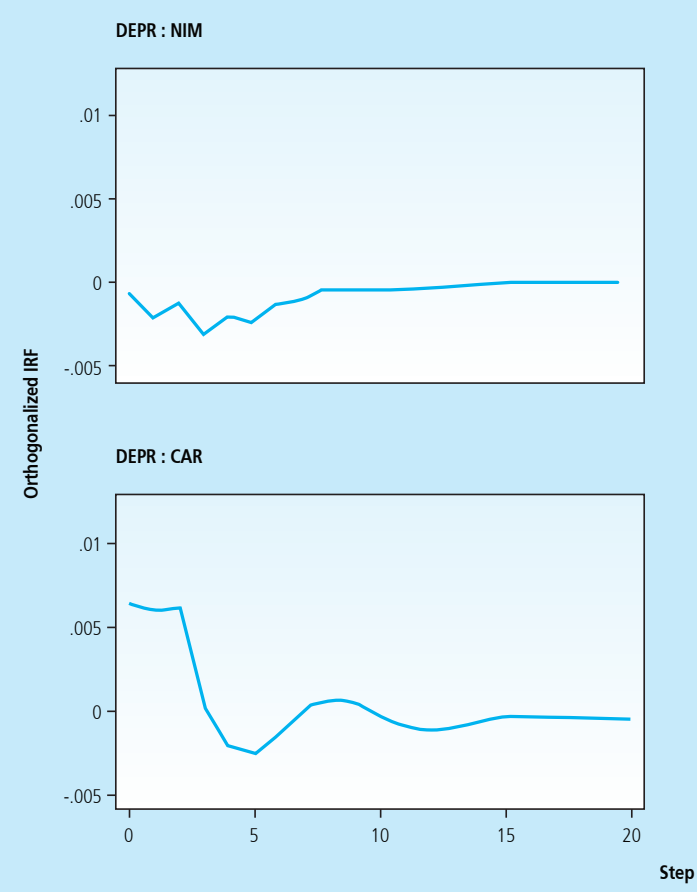

DEPR : NPL

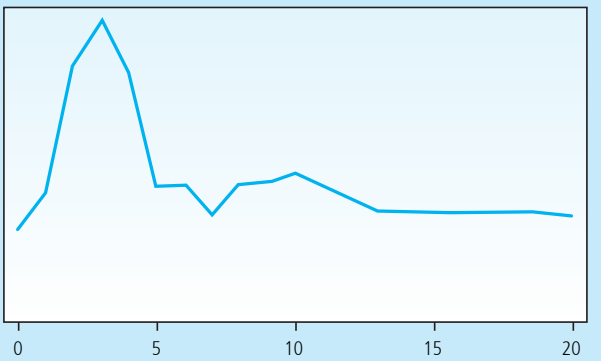

Impluse : response

Grafik 5.

Impulse Response Function Model 2 BUKU 1 
Perekonomian Indonesia sangat terpengaruh oleh stabilitas nilai tukar, mengingat perekonomian Indonesia sangat bergantung pada aktivitas ekspor dan impor. Grafik 5 menjelaskan Impulse Response Function bank-bank pada kelompok modal inti terkecil, dari Rp100 miliar sampai di bawah Rp1 triliun. NPL merespon positif pada saat terjadinya Depresiasi nilai tukar. Respon pada awal periode langsung meningkat positif pada periode ke 2. Respon lalu menurun berangsur-angsur sampai akhirnya hilang. Awalnya NIM tidak merespon saat terjadinya impulse nilai tukar, namun merespon negatif secara perlahan beberapa periode kemudian, lalu berangsur-angsur hilang mulai periode ke 5. Kelompok Bank BUKU 1 yang memiliki rasio CAR paling tinggi perespon positif diawal terjadinya impulse, kemudian respon berangsur-angsur turun dengan cepat dan akhirnya hilang.

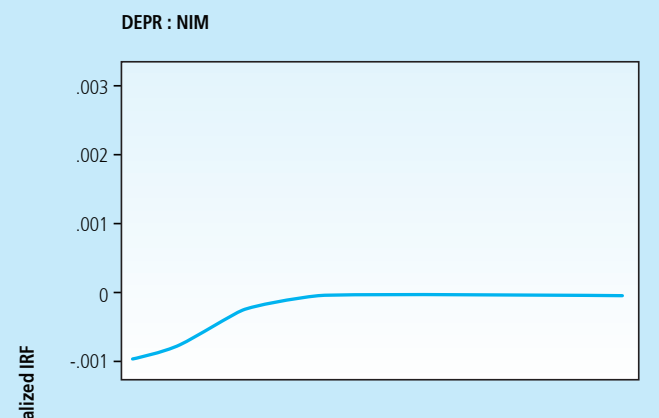

DEPR : NPL

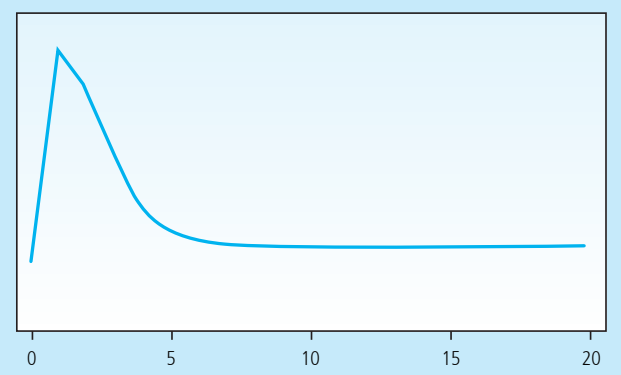

DEPR : CAR

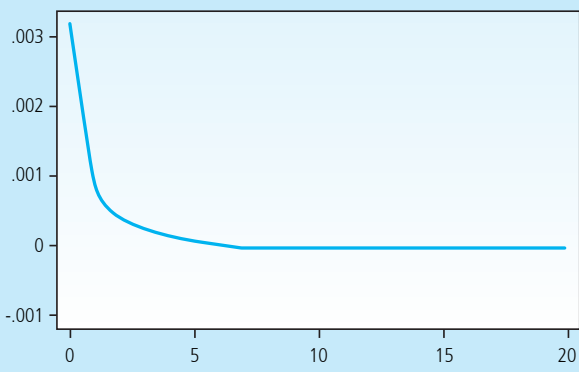

Step

Impluse : response

Grafik 6.

Impulse Response Function Model 2 BUKU2

Perilaku yang sama diperlihatkan pada Grafik 6, dimana Impulse Response Function bank-bank pada kelompok modal inti terkecil, dari Rp100 miliar sampai di bawah Rp1 triliun. NPL merespon positif pada saat terjadinya Depresiasi nilai tukar. Respon pada awal periode 
langsung meningkat positif pada periode ke 2. Respon lalu menurun berangsur-angsur sampai akhirnya hilang. Variabel NIM merespon negatif pada saat terjadinya impulse. Dimulai dari respon negatif kemudian berangsur-angsur hilang pada 5 periode selanjutnya. Perilaku respon CAR kedua kelompok mirip. Kedua kelompok memperlihatkan rata-rata CAR yang paling besar di kelompoknya.

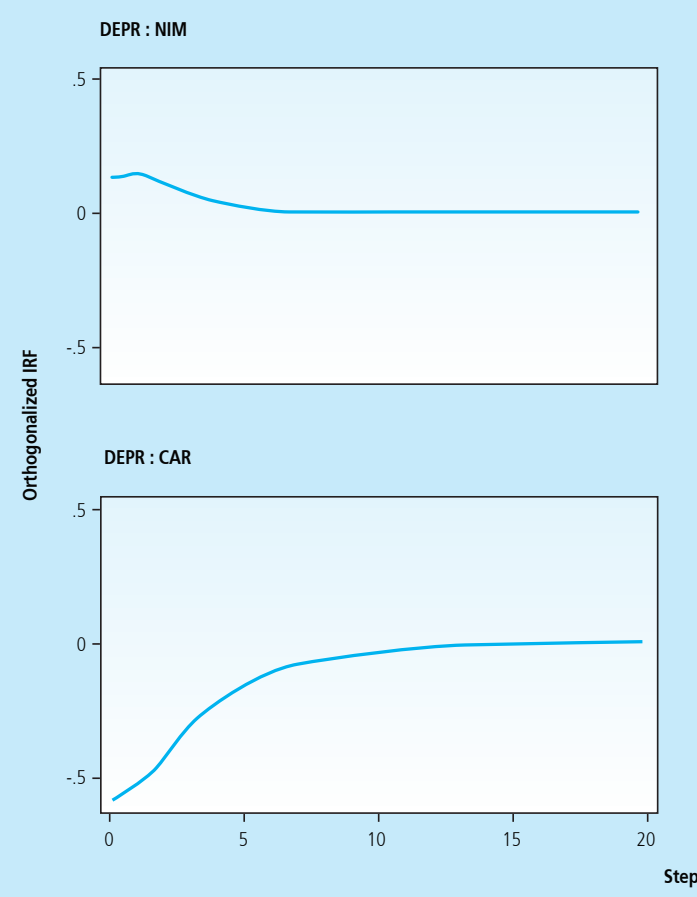

DEPR : NPL

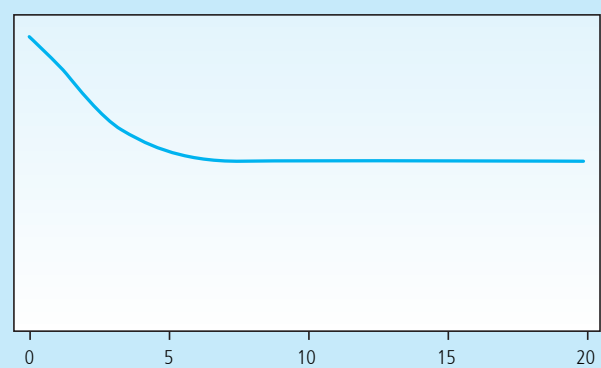

Grafik 7.

Impulse Response Function Model 2 BUKU3

Grafik 7 untuk BUKU 3 dan panel kanan untuk BUKU 4 memperlihatkan perilaku yang sama tetapi sangat berbeda dibandingkan dengan kelompok BUKU 1 dan BUKU 2. Perbedaan terjadi terutama pada respon negatif CAR di awal periode akibat depresiasi nilai tukar. Model kedua dimana orde transmisi dimulai dari Depresiasi dan diikuti dengan NPL, NIM dan CAR mengakibatkan penurunan CAR yang sukup besar. Penyebab dari perubahan ini berasal dari NPL yang merespon positif pada awal periode cukup besar. NPL kedua kelompok ini paling besar diantara 4 kelompok. Namun kedua kelompok ini merespon NIM positif diawal periode. Meskipun terjadi peningkatan NPL, bank ini masih mampu menghasilkan keuntungan dari difersifikasi produk yang berbasiskan suku bunga (interest based income). 


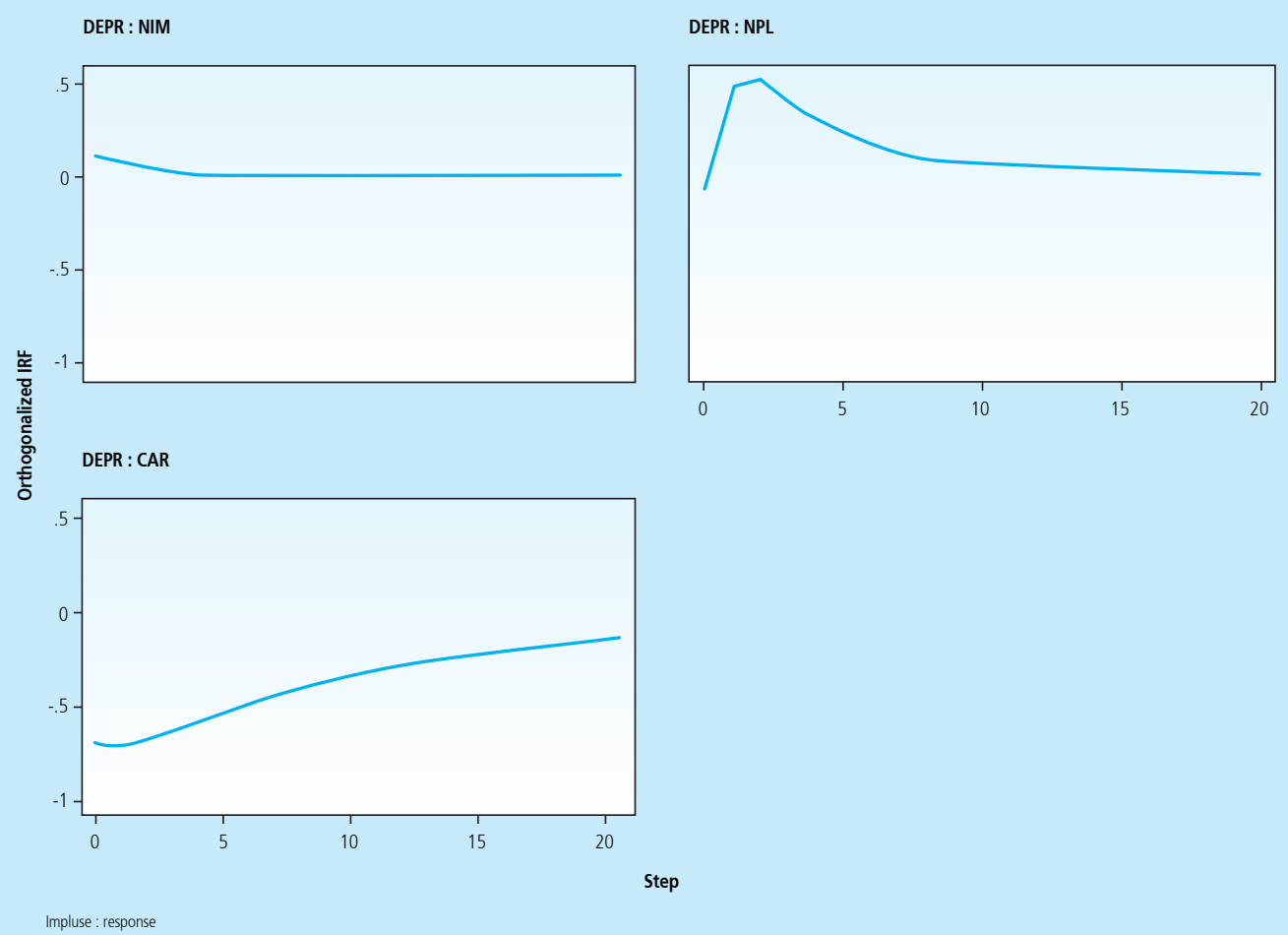

Grafik 8.

Impulse Response Function Model 2 BUKU4

Bank pada kelompok ini tergolong bank yang besar dan memiliki produk berbasis valuta asing (exchange rate). Depresiasi tentunya akan menyebabkan kerugian pada produk ini sehingga akan menurunkan CAR secara sistematis. Hal ini berbeda dengan kelompok bank BUKU 1 dan 2, CAR merespon positif adanya depresiasi nilai tukar kemungkinan disebabkan sebagian besar bank tidak memiliki produk berbasis valuta asing.

Tabel dibawah ini menjelaskan peranan perubahan antar variabel dalam sistem dinamis akibat adanya impulse variabel suku bunga domestik pada model pertama BUKU 1 sampai dengan BUKU4. Pengukuran peran menggunakan variance decomposition dengan metode yang dikembangkan oleh Love (2002) dan Love (2006). Pada model ini urutan transmisi dimulai dari suku bunga domestik, pertumbuhan ekonomi, rasio NPL, net interest margin (NIM) lalu CAR. Pada semua BUKU, peranan IRD dalam sistem dinamis PVAR paling besar karena shock terjadi pada suku bunga domestik kemudian diikuti dengan variabel lain sesuai dengan model. Pada semua kelompok bank, peran variabel mulai stabil pada periode ke 11. Pada periode ini, komposisi peran variabel selain IRD semakin besar, namun komposisi terbesar tetap pada IRD. 


\begin{tabular}{|c|c|c|c|c|c|c|}
\hline \multicolumn{7}{|c|}{$\begin{array}{c}\text { Tabel } 4 . \\
\text { Panel Variance Decomposition Model } 1\end{array}$} \\
\hline Kelompok & Periode & IRD & GROWTH & NPL 5 & NIM 3 & CAR 4 \\
\hline \multirow[t]{5}{*}{ BUKU 1} & Periode & IRD & GROWTH & NPL 5 & NIM 3 & CAR 4 \\
\hline & 1 & 0.87121 & 0.117977 & 0.001055 & 0.009232 & 0.000525 \\
\hline & 5 & 0.831903 & 0.144584 & 0.002415 & 0.016027 & 0.005071 \\
\hline & 10 & 0.830404 & 0.14476 & 0.002545 & 0.016558 & 0.005733 \\
\hline & 11 & 0.830384 & 0.144761 & 0.002546 & 0.016561 & 0.005747 \\
\hline \multirow[t]{3}{*}{ BUKU 2} & 1 & 0.860024 & 0.123029 & 0.011442 & 0.000307 & 0.005198 \\
\hline & 5 & 0.763618 & 0.216974 & 0.013814 & 0.001565 & 0.004029 \\
\hline & 10 & 0.76319 & 0.216991 & 0.013864 & 0.00161 & 0.004345 \\
\hline \multirow[t]{4}{*}{ BUKU 3} & 1 & 0.834646 & 0.126334 & 0.000886 & 0.006037 & 0.032096 \\
\hline & 5 & 0.723977 & 0.201704 & 0.001902 & 0.019154 & 0.053263 \\
\hline & 10 & 0.720428 & 0.201062 & 0.002153 & 0.019705 & 0.056652 \\
\hline & 11 & 0.720358 & 0.201048 & 0.002158 & 0.019711 & 0.056726 \\
\hline \multirow[t]{4}{*}{ BUKU 4} & 1 & 0.740234 & 0.129473 & 0.006376 & 0.078755 & 0.045162 \\
\hline & 5 & 0.687559 & 0.211564 & 0.043366 & 0.039467 & 0.018044 \\
\hline & 10 & 0.688306 & 0.213118 & 0.048158 & 0.03479 & 0.015629 \\
\hline & 11 & 0.688344 & 0.213198 & 0.048285 & 0.034648 & 0.015524 \\
\hline
\end{tabular}

Pada semua BUKU, urutan peran variabel terbesar pertama dan kedua adalah IRD dan Growth. Peran variabel NPL, NIM lalu CAR berbeda-beda pada setiap kelompok bank. Peran IRD terbesar pada BUKU 1, BUKU 2, BUKU 3 lalu terkecil pada BUKU 4. Peran NPL terbesar pada BUKU 4 dan terkecil pada BUKU 1. Demikian pula peran NIM terbesar pada BUKU 4 dan terkecil pada BUKU 1. Peran CAR dalam dampak dinamis PVAR terbesar pada BUKU 3 dan terkecil ada BUKU1.

Tabel dibawah ini menjelaskan peranan perubahan antar variabel dalam sistem dinamis akibat adanya impulse variabel depresiasi nilai tukar pada model kedua BUKU 1 sampai dengan BUKU 4. Pada model ini urutan transmisi dimulai dari depresiasi, suku bunga domestik, rasio NPL, Net Interest Margin (NIM) lalu CAR. Pada semua BUKU, peranan Depresiasi dalam sistem dinamis PVAR paling besar karena shock terjadi pada suku bunga domestik kemudian diikuti dengan variabel lain sesuai dengan model. Pada semua kelompok bank, peran variabel mulai stabil sesudah periode ke 10. Pada periode ini, komposisi peran variabel selain depresiasi semakin besar, namun komposisi terbesar tetap pada depresiasi. 


\begin{tabular}{|c|c|c|c|c|c|}
\hline \multicolumn{6}{|c|}{$\begin{array}{c}\text { Tabel } 5 . \\
\text { Panel Variance Decomposition Model } 2\end{array}$} \\
\hline Kelompok & Periode & DEPR & NPL & CAR & NIM \\
\hline \multirow[t]{4}{*}{ BUKU 1} & 1 & 0.754478 & $1.08 \mathrm{E}-05$ & 0.019597 & 0.002 \\
\hline & 5 & 0.55172 & 0.011644 & 0.01841 & 0.050639 \\
\hline & 10 & 0.566058 & 0.012437 & 0.016265 & 0.072227 \\
\hline & 20 & 0.576619 & 0.013266 & 0.015674 & 0.075791 \\
\hline \multirow[t]{4}{*}{ BUKU 2} & 1 & 0.93346 & 0.000132 & 0.006832 & 0.003874 \\
\hline & 5 & 0.888544 & 0.03819 & 0.004857 & 0.008531 \\
\hline & 10 & 0.888241 & 0.038272 & 0.004791 & 0.008671 \\
\hline & 20 & 0.888241 & 0.038272 & 0.004791 & 0.008671 \\
\hline \multirow[t]{4}{*}{ BUKU 3} & 1 & 0.940235 & 0.029022 & 0.018985 & 0.011758 \\
\hline & 5 & 0.905994 & 0.045419 & 0.024418 & 0.024169 \\
\hline & 10 & 0.905318 & 0.045628 & 0.024618 & 0.024435 \\
\hline & 20 & 0.905315 & 0.045629 & 0.02462 & 0.024436 \\
\hline \multirow[t]{4}{*}{ BUKU 4} & 1 & 0.914083 & 0.000313 & 0.056857 & 0.028747 \\
\hline & 5 & 0.871205 & 0.035 & 0.074913 & 0.018882 \\
\hline & 10 & 0.863304 & 0.039606 & 0.080737 & 0.016353 \\
\hline & 20 & 0.860346 & 0.040174 & 0.082475 & 0.017005 \\
\hline
\end{tabular}

Peran depresiasi terbesar pada BUKU 3, BUKU 4, BUKU 2 lalu terkecil pada BUKU 1. Peran NPL terbesar pada BUKU 3 dan terkecil pada BUKU 1. Demikian pula peran NIM terbesar pada BUKU 1 dan terkecil pada BUKU 2. Peran CAR dalam dampak dinamis PVAR terbesar pada BUKU 4, BUKU 3 dan terkecil ada BUKU2.

\section{KESIMPULAN}

Analisis panel VAR yang dilakukan pada paper ini mempertimbangkan kondisi hetogenitas (keberagaman) bank dalam kelompok BUKU dengan menggunakan fixed effect, dampak dinamis data internal bank, kondisi ko integrasi data panel bank-bank menurut kelompok BUKU, penggunaan data eksogen sebagai kontrol model dan mempertimbangkan dampak interdependensi antar bank secara dinamis.

Respon dinamis merupakan dampak gabungan antar waktu dan antar variabel diperlihatkan pada grafik IRF pada periode 1 dan seterusnya. Respon dinamis menggambarkan bagaimana variabel ekonomi merespon perubahan variabel yang ditransmisikan kepada variabel lainnya dari waktu-kewaktu. Secara umum respon NIM, NPL dan CAR semakin lama menghilang. Kondisi ini ditunjang oleh status stationeritas dan adanya kointegrasi data panel pada semua kelompok Bank. 
Beberapa kesimpulan dapat disampaikan melalui penelitian ini. Pada model pertama (jalur suku bunga) dampak seketika (contemporaneous) diperlihatkan pada grafik IRF pada saat $\mathrm{t}=0$, yang menunjukkan bahwa peningkatan suku bunga (shock) akan menyebabkan penurunan NIM dan peningkatan rasio NPL pada bank-bank yang tergabung pada kelompok BUKU 1 dan 2. Tidak demikian halnya pada bank yang beraset lebih besar (BUKU 3 dan 4) terjadi penurunan NIM dan penurunan rasio NPL. Bukti ini menunjukkan bank dengan aset modal lebih kecil kurang mampu untuk segera menyesuaikan diri menghadapi perubahan suku bunga domestik sehinga rasio NPL segera meningkat. Fenomena peningkatan suku bunga ternyata menyebabkan penurunan CAR pada seluruh kelompok. Penurunan terbesar terjadi pada BUKU 3 dan 4, yaitu bank dengan modal tinggi.

Pada model ke dua (jalur nilai tukar) dampak seketika (contemporaneous) menunjukkan bahwa depresiasi nilai tukar rupiah terhadap dollar US akan menyebabkan penurunan NIM dan peningkatan rasio NPL pada bank-bank yang tergabung pada kelompok BUKU 1 dan 2. Tidak demikian halnya pada bank yang beraset lebih besar (BUKU 3 dan 4) terjadi peningkatan NIM dan penurunan rasio NPL (cukup kecil). Bukti ini menunjukkan bank dengan aset modal lebih kecil kurang mampu untuk segera menyesuaikan diri menghadapi perubahan depresiasi sehinga rasio NPL segera meningkat. Fenomena peningkatan depresiasi nilai tukar ternyata menyebabkan penurunan CAR pada BUKU 1 dan 2. Depresiasi justru meningkatkan CAR untuk BUKU 3 dan 4.

Secara umum bank dengan jumlah modal lebih kecil kurang mampu untuk segera menyesuaikan diri menghadapi peningkatan rasio NPL akibat dari depresiasi nilai tukar, oleh karenanya bank-bank dengan modal lebih kecil harus berhati-hati menghadapi risiko nilai tukar. Penelitian ini merekomendasikan perlunya institusi moneter dan perbankan memberikan kebijakan penyehatan portofolio kredit pada kelompok bank beraset kecil jika terjadi goncangan pada suku bunga dan nilai tukar. Agar langkah-langkah pencegahan dapat berjalan secara efektif, bank dengan modal rendah agar memperhatikan portofolio kredit jika terjadi gejolak nilai tukar. Bank Indonesia perlu memberi edukasi kepada bank dengan modal rendah dan memperketat pengawasan pada bank dengan modal rendah pada saat terjadi gejolak nilai tukar. Tindakan hedging mutlak harus dilakukan untuk mengurangi risiko akibat fluktuasi nilai tukar rupiah. Bank Indonesia perlu menyiapkan sejumlah langkah untuk meminimalkan risiko tekanan terhadap nilai tukar rupiah diantaranya Pengelolaan utang luar negeri, penguatan ekspor, stabilisasi pasar keuangan, memperketat pengawasan arus masuk modal dan pengembangan desain laporan keuangan BI yang dapat mengakomodir transaksi dan transparansi pencatatan keuangan likuiditas valas. Sedangkan kebijakan restrukturisasi kinerja bank perlu dilakukan pada bank dengan aset besar, karena peningkatan suku bunga ternyata menyebabkan penurunan CAR lebih tinggi pada kelompok bank beraset besar. 


\section{DAFTAR PUSTAKA}

Altunbas, Y., Liu, M. H., Molyneux, P., dan Seth, R. 2000. Efficiency and Risk in Japanese Banking. Journal of Banking and Finance. 24: 1605-1628.

Benes, J. 2014. Estimate Panel VAR. The IRIS Toolbox Project.

Breitung, J. 2000. "The Local Power of Some Unit Root Tests for Panel Data" in B. Baltagi (2nd ed.), Advances in Econometrics, Vol. 15: Nonstationary Panels, Panel Cointegration, and Dynamic Panels. Amsterdam: JAI Press.

Breitung, J. dan Pesaran, M.H. 2008. "Unit Roots and Cointegration in Panels" in Mátyás, László and Patrick Sevestre, eds., The Econometrics of Panel Data, Berlin: Springer-Verlag Berlin Heidelberg.

Buncic, D. dan Melecky, M., 2012. Macroprudential Stress Testing of Credit Risk - A Prac-tical Approach for Policy Makers. World Bank Policy Research. Working Paper. 5936.

Canovaa. F. dan Ciccarelli. M. 2004. Forecasting and turning point predictions in a Bayesian panel VAR model. Journal of Econometrics. 120: 327 - 359.

Choi, I. 2001. Unit Root Tests for Panel Data. Journal of International Money and Finance. 20: 249- 272.

Cooley, T. dan Dwyer, M. 1998. Business Cycle Analysis without much Theory: A Look at Structural VARs. Journal of Econometrics. 83: 57-88.

Ekananda, M. 2014. Time Series Analysis for Research in Economy and Business. Publisher : Mitra Wacana Media, Jakarta.

Ekananda, M. 2016. Data Panel Analysis for Research in Economy and Business. 2nd Ed, Publisher : Mitra Wacana Media, Jakarta.

Enders, W. 2005. Applied Econometrics Time Series. John Wiley and Sons, Inc, New York.

Faust, J. dan Leeper, E. 1997. Do Long Run Restrictions Really Identify Anything?. Journal of Business and Economic Statistics. 15: 345-353.

Farhan, M. 2012. Economic Determinants of Non-Performing Loans: Perception of Pakistani Bankers. European Journal of Business and Management. 4 (19).

Firmansyah, I. 2014. Determinant of Non Performing Loan: The Case Of Islamic Bank In Indonesia. Buletin Ekonomi Moneter dan Perbankan. 17 (2).

Girardone, C., Molyneux, P., dan Gardener, E. P. 2004. Analysing the Determinants of Bank Efficiency: The Case of Italian Bank. Applied Economics. 36: 215-227. 
Gosh, A. 2015. Banking-industry specific and regional economic determinants ofnon-performing loans: Evidence from US States. Journal of Financial Stability. 93 (104).

Greene, W.H. 2008. Econometric Analysis, Macmillan Publishing Company, Fifth Edition, New York.

Hadri, K. 2000. Testing for Stationarity in Heterogeneous Panel Data. Econometric Journal. 3:(148-161).

Hamilton, D. 1994. Time Series Analysis. Princeton University Press.

Holtz-Eakin, D., Newey, W., dan Rosen, H.S. 1988. Estimating Vector Autoregressions with Panel Data. Econometrica. 56 (6): 1371-1395. Published by: The Econometric Society

Hughes, J. P., dan Mester, L. J. 1993. A Quality and Risk-adjusted Cost Function for Banks: Evidence on the 'Too-Big-to-Fail' Doctrine. Journal of Productivity Analysis. 4: 293- 315.

Im, K. S., M. H. Pesaran, dan Shin. 2003. Testing for Unit Roots in Heterogeneous Panels. Journal of Econometrics. 115: 53-74.

Islam, M. S., dan Nishiyama, S.I. 2016. The determinants of bank net interest margins: A panel evidence from South Asian countries. Research in International Business and Finance. 37: 501-514.

Jim'enez, G., J. dan Saurina. 2004. Collateral, Type of Lender and Relationship Banking as Determinants of Credit Risk. Journal of Banking and Finance. 28 (9): 2191-2212.

Kao, C. dan Chiang, M. 2000. On the Estimation and Inference of a Cointegrated Regression in Panel Data. in Baltagi, B. H. et al. eds. Nonstationary Panels. Panel Cointegration and Dynamic Panels. 15. Amsterdam: Elsevier. 179-222.

Kao, C., Chiang, M, dan Chen, B. 1999. International R\&D Spillovers: An Application of Estimation and Inference in Panel Cointegration. Oxford Bulletin of Economics and Statistics. 61: 693-711.

Levin, A., C. F. Lin, dan C. Chu. 2002. Unit Root Tests in Panel Data: Asymptotic and FiniteSample Properties. Journal of Econometrics. 108: 1-24.

Long J., dan Plosser, C. 1983. Real Business Cycles. Journal of Political Economy. 91: 39-69. Louis, D.P., Vloudis, A.T., dan Metaxas, V.L. 2011. Macroeconomic and Bank-specific Determinants of Non-performing Loans in Greece: A Comparative Study of Mortgage, Business and Consumer Loan Portfolios. Journal of Banking \& Finance. 201-215.

Love, I. dan Zicchino, L. 2006. Financial development and dynamic investment behavior: Evidence from Panel VAR. Quarterly Review of Economics and Finance. 46 (2): 190-210. 
Love, I., dan Zicchino, L. 2002. Financial development and dynamic investment behavior: Evidence from Panel VAR. The World Bank. Development Research Group. Finance.

Maddala, G. S. dan Wu, S. 1999. A Comparative Study of Unit Root Tests with Panel Data and a New Simple Test. Oxford Bulletin of Economics and Statistics. 6: 631-652.

Misra, B.M., Sarat Dhal. 2010. Pro-Cyclical Management of Non-Performing Loans by The Indian Public Sector Banks. BIS Asian Research Papers. June.

Pesaran, M. 2004. General Diagnostic Tests for Cross Section Dependence in Panels. Cambridge Working Papers in Economics no. 435 and CE-Sifo Working Paper Series no. 1229, University of Cambridge, Cambridge, United Kingdom.

Pedroni, P. 2000. Fully Modified OLS for Heterogeneous Cointegrated Panels. in Baltagi, B. H. ed., Nonstationary Panels. Panel Cointegration and Dynamic Panels. 15. Amsterdam: Elsevier. 93-130.

Pedroni, P. 2001. Purchasing Power Parity Tests in Cointegrated Panels. The Review of Economics and Statistics. 83: 727-731.

Pesaran, M.H. 2007. A Simple Panel Unit Root Test in The Presence of Crosssection Dependence. Journal of Applied Econometrics. 27(2): 265-312.

Ranjan, R. dan Dahl, S.C. 2003. Non-Performing Loan and Terms of Credit of Public Sector Banks in India : An Emperical Assessment. Reserve Bank of India Occasional Papers. 24 (3): 81-121.

Salas, V. dan J. Saurina. 2002. Credit Risk in Two Institutional Regimes: Spanish Commercial and Savings Banks. Journal of Financial Services Research. 22 (3): 203-24.

Shu, C. 2002. The Impact of macroeconomic environment on the asset quality of Hong Kong's banking sector. Hong Kong Monetary Authority Research Memorandums.

Stiglitz, J.E. 2010. Lessons from the Global Financial Crisis of 2008. Seoul Journal of Economics. 23 (3).

Wu, Chang dan Selvili. 2003. Banking System, Real Estate Markets and Non Performing Loans. International Real Estate Review. 6 (1): 43-62. 